\title{
The Ethical Philosophic Dimension of Responsibility in Mitigating the COVID-19 Disaster in Indonesia
}

\author{
Sigit Sapto Nugroho ${ }^{1 *}$, Sarjiyati ${ }^{1}$, Anik Tri Haryani ${ }^{1}$, Yuni Purwati ${ }^{1}$, Arief Budiono ${ }^{2}$, Heru Kuswanto $^{3}$ \\ ${ }^{1}$ Faculty of Law, Universitas Merdeka Madiun, Java, Indonesia; ${ }^{2}$ Faculty of Law, Universitas Muhammadiyah Surakarta, \\ Surakarta, Indonesia; ${ }^{3}$ Faculty of Law, Universitas Narotama, Surabaya, Indonesia
}

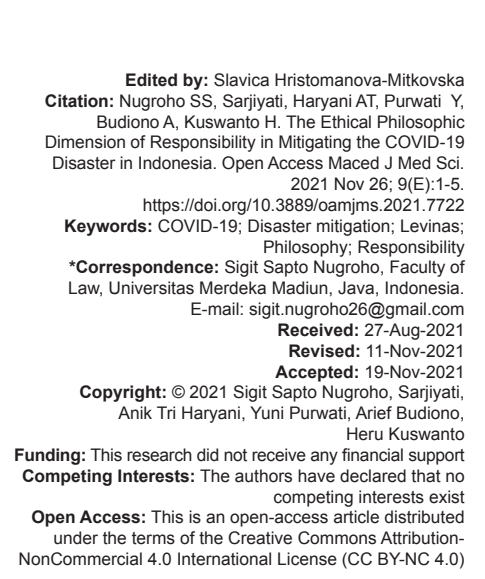

Introduction

Coronavirus disease (COVID-19) was first detected in Wuhan, China. It can spread through droplets when humans interact. Gradually, this virus resulted in 8.000 deaths in the first 50 days. Then, it spread to more than one hundred countries in the world [1]. Countries made efforts to mitigate the COVID-19 disaster [2]. Mutual solidarity is the key to preventing the spread of this virus [3]. Various policies have been issued by the Indonesian government to deal with this pandemic, but they are useless without the people's participation in complying with them [4]. The interests of the state are far more important, as stated in the principle of "Salus Populi Suprema Lex Esto." The safety of the people is the highest law [5].

This paper aims to show that the philosophy of responsibility ethics to others is not merely normative, but is the most basic fact, as stated by Emmanuel Levinas' philosophy in handling the COVID-19 disaster in Indonesia. Pain and suffering are inseparable from social responsibility. This concept is confirmed in dealing with the pandemic through the concept of an ethical philosophy of responsibility, based on Emanuel Levinas' thoughts which are centered on the ethics of responsibility towards others.

\section{Methods}

This research uses the normative or doctrinal method [6]. It uses philosophical and normative approaches [7]. This research is based on the analysis of Emmanuel Levinas's philosophical background of ethical responsibilities and its empirical application in mitigating the COVID-19 disaster in Indonesia. It uses qualitative analysis as it relies on the depth of the data. Considering that this research uses philosophical and normative approaches, it uses secondary data [8]. The data are sourced from philosophical thoughts and legal ideas that grow dialectically.

\section{Results}

\section{Solidarity with shared responsibilities}

Mitigation is carried out as an effort to minimize the risks that occur in disasters. Mitigation is a series of efforts to reduce risks of disaster, through physical development as well capacity building in dealing with disaster [9]. A disaster is any event that causes 
environmental damage, geological disturbance, loss of human life, or health status deterioration, requiring a rapid response from outside the community. This paper discusses the disaster of the COVID-19 outbreak that deteriorates the degree of public health [10].

The World Health Organization stated that as mitigation to prevent the spread of COVID-19, people must wash hands frequently with soap or hand sanitizer and avoid touching the face and practice physical distancing. The mitigation includes educating people on this disease, to make them more responsive and alert [11].

Disaster education is essentially one aspect of environmental life. The conception of disaster education is an educational process about human relations with nature and the built environment, including the management of human relations with natural dynamics, pollution, and the spread of viruses that occur.

The Belgrad International Conference on Environmental Education outlines the functions of disaster education, including [12]:

1. Awareness: Raising people's awareness of the related problems

2. Knowledge: Increasing people's understanding of the environment, related problems, and people's important roles and responsibilities

3. Attitude: Increasing people's strong sense of concern for the environment and motivating them to play an active role in environmental protection

4. Skills: Helping people evaluate environmental requirements with educational programs on ecology, politics, economy, social, esthetics, and education

5. Participation: Helping people develop a sense of responsibility and urgency toward an environmental problem so that they can take relevant actions to solve them.

In the current context, people's awareness of their rights and responsibilities as citizens are required. Building citizen awareness is not easy; it is influenced by many things. Moreover, in the past decade, the Indonesian people are faced many things that often divide society into several opposing interest groups. The COVID-19 disaster should motivate the different community groups as well as the government to reunite [13].

The people's obedience to the COVID-19 pandemic disaster mitigation is influenced and driven by several reasons, namely [14]:

1. The choice between not caring and saving oneself by obeying health protocols and practicing physical distancing. Of course, everyone chooses to save themselves from the spread of COVID-19, as advised by the government. This virus is very easily spread and can be deadly. Thus, the Indonesian government issued restricting policies with various consequences.

2. Moral obligations of humanity. Everyone has the moral obligation of humanity to maintain communal health and safety. Even though this moral obligation of humanity is coercive, in practice it is not absolute. This depends on the people's sense of community and the conscience awareness levels of each member of the community. In the province of Central Java, there is the term "Jogo Tonggo" meaning "taking care of neighbors." It is a pearl of local wisdom that increases the sense of social solidarity between neighbors. Solidarity with shared responsibility is the relationship between individuals or groups that are based on moral feelings and shared beliefs. Social solidarity during this pandemic occurred due to culture, the bond between each member of the community to need each other [15].

3. Maintaining social harmony in society.

4. The existence of threatening legal sanctions.

\section{Ethics philosophy of responsibility}

Emmanuel Levinas is a postmodern thinker who was rather popular in the $20^{\text {th }}$ century, especially in the field of ethics [16]. Levinas' thought deeply touches on the essential elements of human life. Although the concept of ethics is metaphysical in nature, his thoughts on ethics, especially on the concept of responsibility, are very radical and touch the reality of human daily life [17]. A general facticity states that humans cannot be separated from other people. Man becomes human so long as he admits that he is always related to others [18].

As previously described, the COVID-19 pandemic phenomenon opens the awareness on the social aspect of responsibility toward the health of others. The emergence of COVID-19 should change attitudes and patterns, especially after the WHO declared COVID-19 as a pandemic. People should not only take care of their health but they are also responsible for the health of others. Various disaster mitigation policies, especially health protocols, have been introduced and socialized by the government. People are encouraged to stay at home and even work from home. Those forced to leave their homes must wear masks, keep their distance, avoid crowds, and reduce mobility. Masks prevent people from being transmitted and prevent them from transmitting diseases to others. People are not only responsible for their own lives but they are also responsible for the lives of others [19].

Based on these conditions, it can be said that the COVID-19 pandemic has changed people's level of awareness of responsibility. If the health protocol that requires people to wear masks is considered as a violation of people's rights, then that freedom must 
be limited to increase responsibility. The government, medical workers, and law enforcers must limit people's freedom to increase responsibility toward others. Everyone must limit his/her freedom by staying at home, keeping distances, and avoiding crowds to increase responsibility. The responsibility for the safety of others demands great attention. Even if freedom is defined as the autonomous freedom to make responsible decisions, then one must take responsibility for others as part of it.

According to Emmanuel Levinas, the most basic fact that can be the beginning of philosophy is my responsibility to others [20]. Therefore, the main material in philosophy is ethics, not metaphysics. Metaphysics departs from ethics. If metaphysics, according to Aristotle, is the main part of philosophy, then that metaphysics is ethics instead of phenomenon (Husserl), ontology (Heidegger), or consciousness (Descartes). For him, this ethical responsibility is not normative but is the main basic fact that underlies human ethical actions and behavior [21].

Emmanuel Levinas's thoughts remind us of the traditional collective thought concept, which defines illness as part of irresponsible attitudes and behavior toward others. COVID-19 seems to be a momentum that reminds us to reflect on the relationship between illness, health, and social behavior -- that illness and health are part of the collective social affairs. Likewise, disease prevention and recovery are not only the personal area of responsibility but are an area of responsibility for others [22].

The COVID-19 pandemic has repositioned the ethical aspect in all phenomena in human life, including medical phenomena, that in fact, medical problems will be handled when the ethical aspects are taken care of as well. Paying attention to others with actions such as sharing and caring is the key to preventing the transmission of this disease or in mitigating it. Wearing a mask, washing hands, and avoiding crowds are signs of my ethical responsibility to others.

Levinas builds his philosophy on the most basic fact that there are other people who "show their faces to me." For Levinas, the appearance of another person's face is the most basic fact before "I became aware of his presence and determined my attitude." It is based on this underlying reality that Levinas builds his philosophy, and therefore, according to him, the main material of philosophy is ethics. And the cornerstone of ethics is other people, the responsibility to others. On this basis, he criticizes all previous philosophies as they are centered on "Me and my consciousness" and not on other people [23].

The COVID-19 pandemic calls for responsibility for the safety of others. There is a shared momentum to care and to be responsible for other people and third parties. This third party is also not the same as anyone else, but it is an infinite series of other people who are also part of the responsibility. Hence, one's responsibility toward others here is not limited to merely other people, but also to unlimited human beings. The third party is the human race. Hence, the mitigation of the COVID19 disaster through the wearing of masks, keeping a distance, avoiding crowds in the face of COVID-19, for example, is not to isolate one from others, but to reveal one's responsibilities toward other people and humanity as a whole. That ethical responsibility leads to transcendence and freedom. Responsibility toward others shows the authenticity of humans as guardians for other humans. This principle is the ethical foundation that will bring peace, prosperity, and social justice to mankind [22].

The COVID-19 pandemic also gave the Indonesian government responsibility on order, security, comfort, and public welfare. Philosophically, the responsibility of the state can be seen in the fourth paragraph of the Preamble to the Republic of Indonesia's 1945 Constitution, which is, "To protect the entire Indonesian nation and the entire homeland of Indonesia, to promote public welfare, to educate the nation's life, and to participate in carrying out world order based on independence, eternal peace, and social justice.

The four responsibilities above are the mandate of the nation's founders for the state administration. Then, we all know that Indonesia is a country that is based on the law (rechtsstaat), not based on power alone [24]. The Constitution of the Republic of Indonesia has a principal position as a guideline for the governance and for the implementation of the state, government, and social life - including affirming the existence of the state concept, as well as an ethical form of state responsibility for its citizens.

The goal of the state is to protect the entire Indonesian nation and the entire homeland of Indonesia. The protection during the pandemic is practiced as the implementation of the philosophy of state responsibility to protect the public from the disease. This responsibility applies to all people both within the country and abroad. The state's responsibility is also contained in Article $28 \mathrm{H}$ of the Republic of Indonesia's 1945 Constitution, that the state is obliged to fulfill health services (Article $28 \mathrm{H}$ Paragraph (1) of the 1945 Constitution), and is obliged to fulfill social security to the community (Article 28H Paragraph (3) the 1945 Constitution).

\section{Discussion}

The state must be responsible for providing proper health service facilities to handle the COVID-19 (Article 34 Paragraph (3) of the 1945 Constitution) in implementing the COVID-19 disaster mitigation policy. It must pay attention to the fulfillment of social security 
and health services for the community. Furthermore, from the human rights perspective, everyone has the right to enjoy the highest attainable standard of physical and mental health during the COVID-19 pandemic.

As a non-natural disaster, the state responsibility and role during the COVID-19 pandemic is contained in Article 6 of Law Number 24 of 2007 concerning Disaster Management (or the Law on Disaster Management). The government is responsible for protecting the people from the impact of disasters. It is responsible for guaranteeing compliance with the rights of communities and refugees affected by disasters fairly and following minimum standards of service and is also responsible for recovering conditions from the impact of disasters. Local governments also have the responsibility of handling COVID-19.

Based on Article 8 of the Law on Disaster Management, during the COVID-19 disaster mitigation, the government must be responsible for guaranteeing the fulfillment of the needs of everyone who has been affected by the COVID-19 pandemic under minimum standards of service. Furthermore, the local government must also protect the community from the impact of COVID-19. It is also responsible for reducing the risk of COVID-19 and for integrating COVID-19 risk reduction with development programs. Then, in the economic aspect, the government is also responsible for allocating the handling and the prevention of COVID19 in the available State Budget.

The ethical philosophy of accountability is a crystallization of human rights protection during the COVID-19 pandemic. This is the basic principle of the state's demand to respect, protect, and fulfill the human rights of every person. During the COVID19 pandemic, the state must be present in providing excellent service to the people's health aspect. In fact, the state must prepare strategic steps to overcome potential crises on all fronts. The protection of public security is also a reflection of the ethical philosophy of state responsibility.

\section{Conclusion}

Medical developments that tend to promote responsibility to others is an effective form of COVID-19 disaster mitigation. Levinas' ethical philosophy, which prioritizes responsibility for others, is more in tune with traditional religious societies because his ethics refers to an infinity that is open to the transcendent. Indonesia is a religious nation that seems to be more comfortable with Levinas' ethical principles, as it shows that responsibility toward others is the most fundamental phenomenon. Levinas' ethics is also more suitable for Indonesian people with very strong collective brotherhood ties. Responsibility for others is a value that is embedded in the practices of civilization in Indonesia, including mutual assistance, helping each other, being friendly, caring for each other, and sharing, which are part of the local wisdom that grows and develops. It is included in the responsibility of the state toward its citizens.

\section{References}

1. Shereen MA, Khan S, Kazmi A, Bashir N, Siddique R. Covid19 infection: Origin, transmission, and characteristics of human coronaviruses. J Adv Res. 2020;24:91-8. http://doi. org/10.1016/j.jare.2020.03.005

PMid:32257431

2. Shadiqi MA, Hariati R, Hasan KF, I'anah N, Al Istiqomah W. Panic buying during the Covid-19 pandemic: A literature review from the psychological perspective. J Psikol Sos. 2020;19(2):131-41.

3. Disantara FP. State responsibility during the Covid-19 pandemic. JCH. 2020;6(1):48-60.

4. Ristyawati A. Effectivity of the large-scale social restriction policy during the Covid-19 pandemic according to the mandate of the Republic of Indonesia's 1945 constitution. Adm Law Gov J. 2020;3(2):240-9

5. Arde-Acquah P. Salus populi suprema lex esto: Balancing civil liberties and public health interventions in modern vaccination policy. Washington Univ Jurisprudence Rev. 2015;7(2):337.

6. Nugroho SS. Legal Research Methodology. Vol. 29. Surakarta: Oase Pustaka; 2020.

7. Samekto FA. Analyzing the root of Hans Kelsen's thought on stufenbeautheorie in the normative-philosophical approach. Hukum Progresif. 2019;7(1):1-19.

8. Suhaimi S. Legal problems and approaches in the normative legal research. Yustitia. 2018;19(2):202-10

9. Nugroho SS, Hilman S. Disaster Mitigation Law in Indonesia. Klaten: Lakeisha; 2020.

10. Burhanuddin Al, Massi MN, Thahir H, Razak A, Surungan T, editors. Staying Strong amid the Covid-19 Pandemic. Yogyakarta: Deepublish; 2020.

11. Setyowati DL, Juhadi J, Pratiwi ES, Yohanes KD, Rahma A. Assistance of disaster preparedness village through landslide disaster education. J Child Educ Soc. 2021;4(3):71-80.

12. Yudiawan A. Disaster mitigation: Covid-19 pandemic management at the early education unit. Pratama Widya. 2020;5(2):112-24.

13. Dharma S. Developing the global awareness of citizens: Study of public policies amid the Covid-19 pandemic. PerspektiF. 2021;10(1):248-54

14. Mahardhani AJ. Becoming a good citizen amid the Covid-19 pandemic: A new normal perspective. JPK. 2020;5(2):65-76.

15. Arditama E, Lestari P. Taking care of neighbours: Raising local wisdom-based citizen awareness and compliance amid the Covid-19 pandemic in Central Java. J Pendidikan Kewarganegaraan Undiksha. 2020;8(2):157-67.

16. Magnis-Suseno F. $20^{\text {th }}$ Century Ethics: Emmanuel Levinas the Call Others. Yogyakarta: Kanisius; 2006.

17. Bergo B. The Oxford Handbook of Levinas. Oxford: OUP; 2019. p. 71.

18. Susanta YK, Putra YY, Christian I. Ethics of responsibilities according to Emmanuel Levinas and its implications for interfaith dialogue: Christian perspectives. Dialog. 2020;43(2):167-76. 
19. Dewi PA, Khotimah H. Parenting amid the Covid-19 pandemic. SENASIF. 2020;4(1):2433-41.

20. Absori A, Nugroho SS, Budiono A, Ellyani E, Nurani SS. Indonesia as an ecocracic country: The state's responsibility and the people's participation in preserving and in managing the environment quality. Calitatea. 2020;21(179):140-3.

21. Molan B. The relevance of Emmanuel Levinas' thought in the context of the Covid-19 pandemic. Respons. 2020;25(2):49-74. https://doi.org/10.25170/respons.v25i02.2464

22. Pranowo $Y$. Transcendence of the thoughts of Simone de Beauvoir and Emmanuel Levinas. Melintas. 2016;32(1):73-93. https://doi.org/10.26593/mel.v32i1.1926.73-93

23. Doren KP. The responsibility concept of Emmanuel Levinas and its implication to Indonesia's diversity. Soc Dei. 2018;5(2):154.

24. Disantara FP. The aspect of immunity in handling Covid-19. Istinbath. 2020;17(1):65-82. 